\author{
Contato \\ Rua Coronel José Guilherme, 33 - casa B \\ 35790-000 - Curvelo - Minas Gerais \\ melizacamp@gmail.com
}

\section{OS INVENTÁRIOS DE DEMENTES: OS PROCESSOS DE CURADORIA E A RELAÇÃO DA JUSTIÇA RÉGIA COM A LOUCURA NAS MINAS GERAIS DO SÉCULO XVIII}

\author{
Maria Eliza de Campos Souza* \\ Centro Federal de Educação Tecnológica de \\ Minas Gerais \\ Curvelo - Minas Gerais - Brasil
}

\title{
Resumo
}

Pretende-se analisar a atuação da Justiça régia em relação a um grupo de súditos que nas Minas viveram a experiência do enlouquecimento e foram declarados incapazes perante a lei. A investigação sobre a atuação dos juízes de órfãos responsáveis pelos autos sumários de demência, pela feitura e condução dos processos de inventários dos dementes e pelo acompanhamento das curadorias permitirá compreender melhor o papel e o alcance dessa Justiça, exercida em nome do rei, no que diz respeito à regulação e ao ordenamento da vida social local. Trata-se de um estudo dos processos de inventários dos indivíduos declarados dementes na Comarca do Rio das Velhas ao longo do século XVIII. São dezesseis processos encontrados para a vila de Sabará e seu termo que permitem compreender uma faceta muito peculiar da atuação dos juízes de órfãos e também a própria história social da loucura nas áreas periféricas do Império português.

\section{Palavras-chave}

Loucura - juizados de órfãos - sumários de demência.

* Doutora pela Universidade Federal de Minas Gerais. Professora do Centro Federal de Educação Tecnológica de Minas Gerais CEFET-MG/Unidade de Curvelo. Artigo produzido a partir de pesquisa financiada de 07/05 a 31/12/2015 no âmbito do programa PMPD III/Acordo CAPES/ Fundação de Amparo à Pesquisa de Minas Gerais - FAPEMIG. 
Contact

Rua Coronel José Guilherme, 33 - casa B 35790-000 - Curvelo - Minas Gerais melizacamp@gmail.com

\section{THE DEMENTED}

INVENTORIES:

THE CURATION

PROCESS AND THE

RELATIONSHIP OF

THE ROYAL JUSTICE

WITH MADNESS IN

MINAS GERAIS OF

THE EIGHTEENTH

CENTURY

\section{Maria Eliza de Campos Souza}

Centro Federal de Educação Tecnológica de Minas Gerais

Curvelo - Minas Gerais - Brazil

\begin{abstract}
We intend to analyze the performance of royal Justice in relation to a group of subjects who lived in Minas maddening experience and were declared incapable under the law. Research on the performance of judges of orphans responsible for the case of dementia summaries by making and conduct of inventories processes of demented and monitoring of curatorship, will better understand the role and scope of that Justice, exercised in the name of the king, in with regard to the regulation and system of the local social life. It is a study of inventories of cases of declared demented individuals in the County of Rio das Velhas during the eighteenth century. There are sixteen processes found for Sabará village and its end, which shed a peculiar facet of the performance of judges of orphans and also the very social history of madness in the peripheral areas of the Portuguese Empire.
\end{abstract}

\title{
Keywords
}

Madness - orphans courts - dementia summaries. 


\section{Introdução}

A discussão sobre a atuação dos juízes de órfãos - os oficiais de Justiça responsáveis pelos autos sumários de demência, pela feitura e condução dos processos de inventários dos dementes e pelo acompanhamento das curadorias - permitirá compreender melhor o papel e o alcance da Justiça, exercida em nome do rei, no que diz respeito à regulação e ao ordenamento da vida social local. Especificamente, o trabalho desenvolvido foi o estudo dos processos de inventários dos indivíduos declarados dementes na Comarca do Rio das Velhas ao longo do século XVIII - cerca de dezesseis processos encontrados para a vila de Sabará e seu termo -, os quais permitem compreender uma faceta muito peculiar da atuação dos juízes de órfãos e também a própria história social da loucura nas áreas periféricas do Império português. São fontes cartorárias que se encontram sob guarda do Museu do Ouro, Casa Borba Gato em Sabará, já bastante exploradas pela produção historiográfica mineira e sobre as Minas setecentistas. Elas têm subsidiado importantes trabalhos no campo da história social, econômica e cultural. ${ }^{1}$

A produção historiográfica brasileira a partir das últimas décadas do século XX demonstrou um grande interesse em retomar as discussões sobre o problema da administração estabelecida por Portugal nas áreas periféricas de seu império colonial, numa perspectiva diferenciada em relação às interpretações existentes. Nessas recentes abordagens sobre a administração portuguesa na América é possível identificar o uso de novas categorias conceituais a embasar pesquisas e trabalhos produzidos sobre o tema ${ }^{2}$ e, sobretudo, uma enorme ampliação dos objetos de estudo, assim como também das fontes documentais utilizadas.

Estabeleceu-se um diálogo efetivo entre historiadores brasileiros e portugueses que buscaram debater os temas mais gerais referentes ao Estado português e seu império ultramarino no Antigo Regime, e até temas mais específicos ligados às peculiaridades de cada área estudada. Atualmente,

\footnotetext{
SANTOS, Raphael Freitas. "Devo que pagarei": sociedade, mercado e práticas creditícias na Comarca do Rio das Velhas (1713-1773). Dissertação de mestrado em História, UFMG, Belo Horizonte, 2005. PAIVA, Eduardo França. Escravos e libertos nas Minas Gerais do século XVIII: estratégias de resistência através dos testamentos. São Paulo: Annablume, 1996. DAVES, Alexandre Pereira. Vaidades das vaidades: os homens, a morte e a religião nos testamentos da Comarca do Rio das Velhas (1716-1755). Dissertação de mestrado em História, UFMG, Belo Horizonte, 1998. Mimeo.

2 HESPANHA, Antonio Manuel. Imbecillitas: as bem-aventuranças da inferioridade nas sociedades de Antigo Regime. São Paulo: Annablume, 2010.
} 
rev. hist. (São Paulo), n. 176, a07616, 2017 http://dx.doi.org/10.11606/issn.2316-9141.rh.2017.121615
Maria Eliza de Campos Souza

Os inventários de dementes: os processos de curadoria e a relação da justiça régia com a loucura nas Minas Gerais do século XVIII

poucos trabalhos propostos não dispõem de um bom número de pesquisas e produções anteriores que permitam estabelecer interlocução efetiva entre seus autores. Júnia Ferreira Furtado ${ }^{3}$ afirma que a renovação historiográfica e a ampliação dos estudos sobre Minas colonial relacionam-se ao crescimento dos programas de pós-graduação em História nas universidades brasileiras, a partir da década de 1950, mas especialmente nas duas últimas décadas do século XX, e que essa produção pode ser dividida em cinco eixos temáticos para efeito de estudo: "1) as relações de poder, as revoltas e as inconfidências; 2) a escravidão; 3) o universo da vida social e familiar; 4) a vida cotidiana e material; e, 5) a cultura e a religiosidade". ${ }^{4}$

No caso do estudo proposto será necessário estabelecer uma interlocução entre pelo menos dois dos eixos temáticos propostos pela autora, e também superar a carência de estudos mais aprofundados sobre o tema loucura no contexto das Minas setecentistas. Nesse sentido, para se tratar dos processos de inventários dos dementes é necessário dialogar com a produção historiográfica que tratou do universo da vida social e familiar, da vida cotidiana e material, assim como abordar as relações de poder para além dos limites institucionais. Relações de poder que se desenvolveram em torno de interesses de familiares nos bens inventariados, ligadas à entrada e administração dos valores liquidados no cofre do juízo dos órfãos, e ainda, o poder de excluir indivíduos do pacto social. ${ }^{5}$

A produção historiográfica existente sobre as Minas setecentistas não contempla, com raras exceções, ${ }^{6}$ especificamente a experiência histórica dos

\footnotetext{
3 FURTADO, Júnia Ferreira. Novas tendências da historiografia sobre Minas Gerais no período colonial. Revista História da Historiografia, nº 02, mar. 2009, p. 117.

4 Idem, p. 120.

5 HESPANHA, António Manuel, op. cit., p. 54.

6 Sobre o contexto das Minas setecentistas, Marco Antônio Silveira analisa um auto sumário de demência para discutir o "problema das tensões relativas à busca de distinção na sociedade mineira setecentista" na segunda metade do século. SILVEIRA, Marco Antonio. Distinção e patetice: o caso do demente Manuel Pereira de Magalhães (Vila Rica, 1769). In: Idem. Dimensões do poder em Minas (séculos XVIII e XIX). Belo Horizonte: Fino Traço, 2012, p. 139-155. E para a Comarca do Rio das Velhas consta um resumo de trabalho publicado nos Anais do II Congresso de Ciências Humanas, Letras e Artes de Minas Gerais que foi apresentado como comunicação oral, quando a autora, Rosana de Figueiredo Ângelo, era bolsista de Iniciação Científica do projeto de banco de dados dos inventários e testamentos do século XVIII, coordenado pela prof.(a) Beatriz Ricardina de Magalhães. Entretanto, a autora não publicou o texto completo em revistas ou outros meios eletrônicos e, conforme currículo Lattes, a autora não desenvolveu outros trabalhos de pesquisa sobre o tema. ANGELO, Rosana Figueiredo. A loucura no século XVIII - Um estudo dos mentecaptos na Comarca do Rio das Velhas. In: II CONGRESSO
} 
indivíduos que nela enlouqueceram e, apesar de existirem muitos trabalhos sobre a administração e a Justiça, seus agentes e funções desempenhadas, dentre outros aspectos, não se deu muita importância à atuação dos juízes de órfãos, especialmente ao seu papel frente às curadorias dos dementes. Os inventários de dementes pesquisados correspondem a uma parte do acervo de inventários e testamentos referentes à Comarca do Rio das Velhas, cuja sede era a vila de Nossa Senhora da Conceição de Sabará e que, nesse caso, foram produzidos no âmbito das atividades do juizado dos órfãos dessa vila ao longo do século XVIII. Nos processos de inventários das pessoas declaradas incapazes encontram-se informações sobre as razões, motivos que desencadearam a feitura do auto sumário de demência, os bens pertencentes a esses indivíduos, sua posição social, profissional, os curadores nomeados, suas prestações de contas e muitas notificações feitas pelos juízes responsáveis. São informações que permitem acompanhar a vida desses indivíduos e as intervenções da Justiça em cada caso, até a morte, quando os processos estão completos.

Nesse sentido, o que se pretende é buscar compreender como funcionou na prática a atuação dos juízes de órfãos quanto aos indivíduos declarados incapazes pela Justiça e o que essa atuação pode revelar e esclarecer para além dos aspectos legais e institucionais sobre como aquela sociedade se relacionou com a loucura e em que medida ela era ou não um problema social.

\section{Os juizados de órfãos em Minas Gerais: seu lugar na estrutura administrativa e judicial e suas atribuições}

Assistimos desde a instalação das primeiras vilas e do aparato administrativo que então se impôs às Minas até 1720 a um período de inquietações e ajustes entre os diversos grupos de poder que compuseram a sociedade mineira. Conforme salienta Donald Ramos, foi a partir de 1720, notadamente após a Revolta de Vila Rica, ${ }^{7}$ que se vislumbrou a instauração de um período

DE CIÊNCIAS HUMANAS, LETRAS E ARTES. Anais. Universidade Federal de Uberlândia, 27 de maio de 1995. Uberlândia: UFU, 1995 (Apresentação de trabalho com resumo publicado). Outro artigo a ser citado é o de Maysa de Pádua Teixeira Paulinelli, mas trata-se de análise do discurso presente nos documentos judiciários e não especificamente sobre a história da loucura. PAULINELLI, Maysa de Pádua Teixeira. Narrativas da demência: análise de gêneros judiciários produzidos na região dos inconfidentes. Entremeios: Revista de Estudos do Discurso, vol. 10, jan.-jun. 2015. Disponível em: < http://www.entremeios.inf.br >. Acesso em: 22/07/2015.

7 Segundo Donald Ramos a Coroa portuguesa enfrentou, a partir de 1711, muitos conflitos com as câmaras municipais e somente conseguiu impor a autoridade real depois da Revolta de Vila Rica em 1720, que resultou na execução de Felipe dos Santos. Para ele o governo de d. Pedro 
de certa "acomodação" ${ }^{8}$ dos interesses dos diversos poderes concorrenciais atuantes em Minas, pelo menos daqueles estabelecidos nas principais vilas e centros administrativos. A questão da instabilidade das "estruturas acomodativas", ${ }^{\prime 9}$ ligada às disputas de poder entre os vários atores políticos, deve ser levada em conta quando se analisa o lugar e papel dos juizados de órfãos nessas estruturas. Ou seja, a acomodação sugerida por Donald Ramos era bastante relativa, quando se observa mais de perto a administração em âmbito local. Joaquim Romero Magalhães, em Concelhos e organização municipal na época moderna, ressaltou a importância dos concelhos municipais tanto no reino quanto no ultramar para a governança régia. O autor afirma que, no caso das Minas, desde o início a Coroa percebeu que não se poderia evitar a autonomia ou total independência das pessoas que "andavam nos descobertos" senão por meio "da constituição dos municípios", porque assim "vinha o Estado a encarrilar os impulsos dos grupos até então sem regras. Para isso, e mais uma vez, havia que promover a fundação de Vilas".10 Charles Boxer, desde 1969 em sua obra O império marítimo português, já havia salientado que as câmaras seriam responsáveis junto com as misericórdias por uma continuidade que outras instituições e cargos da administração da Coroa não eram capazes de garantir.11 Outros autores, e dentre eles Maria Fernanda Bicalho que estudou a Câmara Municipal do Rio Janeiro, chamam atenção para a importância desses órgãos na representação dos interesses e demandas dos colonos frente aos interesses do centro. Portanto, as câmaras também seriam espaços onde os súditos ultramarinos poderiam desfrutar de

de Almeida teria posto um fim à era dos potentados. Somente na década de 1730 voltaram a ocorrer levantamentos significativos no sertão do São Francisco, direcionados contra a imposição da cobrança dos quintos pelo sistema da captação. Isto não significou, entretanto, ausência de conflitos ou enfrentamentos entre as autoridades representantes da Coroa e do poder local. Ver RAMOS, Donald. A social history of Ouro Preto: stresses of dynamic urbanization in colonial Brazil, 1695-1726. Gainesville: University of Florida, 1972.

8 Tomamos emprestado o termo acomodação às reflexões de Carla Maria Junho Anastasia. Anastasia, que afirma ter existido em Minas no século XVIII formas acomadativas caracterizadas pela resolução temporária dos conflitos entre atores coloniais e metropolitanos. Essas formas acomodativas entravam em colapso nos momentos em que se instauravam as revoltas ou motins. ANASTASIA, Carla Maria Junho. América portuguesa: mais direitos, menos revoltas. In: COSENTINO, Francisco Carlos (org.). 1500-2000: Trajetórias. Belo Horizonte: Centro Universitário Newton Paiva Curso de História, 1999.

9 ANASTASIA, Carla Maria Junho, op. cit., p. 50.

${ }^{10}$ MAGALHÃES, Joaquim Romero. Concelhos e organização municipal na Época Moderna. Coimbra: Imprensa da Universidade de Coimbra, 2011, p. 151-152.

${ }^{11}$ BOXER, Charles Ralph. Oimpério marítimo português, 1415-1825. São Paulo: Companhia das Letras, 2002. 
certa autonomia e em determinados momentos até mesmo apresentar uma "certa tendência ao autogoverno".12

Essa abordagem realça a ambiguidade presente nessas estruturas administrativas implantadas pela Coroa e, especificamente no caso de Minas Gerais, os trabalhos de Pablo Menezes e Oliveira, Maria do Carmo Pires e Carmem Silva Lemos ${ }^{13}$ também convidam a pensar no quão controversa foi a atuação das câmaras e oficiais a ela vinculados, os quais por vezes afirmavam e cumpriam o importante papel para consolidação das determinações régias sobre a região como também defendiam de forma intransigente os seus próprios interesses. Reconhecer que a administração e a Justiça exercidas em nome do rei nas Minas comportavam essas ambiguidades é fundamental para compreender a atuação dos juízes de órfãos e o próprio funcionamento do juizado em suas diversas atribuições.

A partir dos episódios da Guerra dos Emboabas, ${ }^{14}$ a Coroa, com o intuito de apaziguar os ânimos e estabelecer um maior controle na região mineradora, criou em 1709 a Capitania de São Paulo e Minas do Ouro, separada desde então da jurisdição da Capitania do Rio de Janeiro e em seguida erigiu no ano de 1711 as três primeiras vilas da nova capitania: Vila do Ribeirão do Carmo, Vila Rica e Vila de Nossa Senhora da Conceição do Sabará. Em 1713, erigiu-se a Vila de São João Del Rei e no ano seguinte foram criadas as três primeiras comarcas e outras duas vilas que eram Vila do Príncipe (atual Serro) e Vila Nova da Rainha (Caeté). Em 1715, foi erigida outra vila na Comarca do Rio das Velhas, a de Nossa Senhora da Piedade do Pitangui, completando três vilas no seu território, e, em 1718, na Comarca do Rio das Mortes erigiuse a segunda vila, a de São José Del Rei. Portanto, entre os anos de 1711 até 1720, a Coroa, com o objetivo de interiorizar a Justiça régia e conseguir um maior controle sobre as áreas estratégicas das Minas, estabeleceu as câmaras como meio para afirmar o seu poder sobre a capitania. Contudo, os incessantes conflitos entre autoridades e as constantes queixas e resistências das

12 BICALHO, Maria Fernanda. A cidade e o Império. Rio de Janeiro: Civilização Brasileira, 2003, p. 258-259.

${ }^{13}$ LEMOS, Carmen Silva. A justiça local: os juízes ordinários e as devassas da Comarca de Vila Rica (17501808). Dissertação de mestrado, Universidade Federal de Minas Gerais, Belo Horizonte, 2003. PIRES, Maria do Carmo. "Em testemunho da verdade": juízes de vintena e o poder local na Comarca de Vila Rica (1736-1808). Belo Horizonte: UFMG, 2005. OLIVEIRA, Pablo Menezes. Cartas, pedras, tintas e coração: as casas de câmara e a prática política em Minas Gerais (1711-1798). Tese de doutorado, Universidade Federal de Minas Gerais, Faculdade de Filosofia e Ciências, 2013.

${ }^{14}$ ROMEIRO, Adriana. Paulistas e emboabas no coração das Minas: ideias, práticas e imaginário político no século XVIII. Belo Horizonte: Editora da UFMG, 2008. 
câmaras em colocar em execução as ordens régias levaram a uma maior resistência quanto à criação de novas vilas, de modo que, ao longo da primeira metade do século se criou apenas mais uma municipalidade que foi a Vila de Nossa Senhora do Bom Sucesso de Araçuaí (1730) e depois, apenas no último quartel do século, foram erigidas novas vilas na capitania, especialmente na Comarca do Rio das Mortes, medida que evidencia o "deslocamento do eixo econômico da Capitania" para essa região em fins do século XVIII. ${ }^{15}$

Além das vilas, o território mineiro possuía muitos arraiais e pequenas localidades que compunham os termos das vilas. Essas informações são fundamentais para quem pretende estudar os juizados de órfãos nas Minas porque eles estavam vinculados à estrutura das câmaras e se constituíam como um dos seus braços na administração da Justiça em âmbito local, responsabilizando-se pelos órfãos e incapazes em todo termo da vila. Renato Pinto Venâncio, ${ }^{16}$ ao estudar a estrutura do Senado da Câmara de Mariana no século XVIII, subdividiu a história dessa municipalidade em duas fases, sendo a primeira de 1711 até 1745 e a segunda de 1745 a 1808 e considera que as atividades desempenhadas pelo juizado de órfãos eram essencialmente de natureza econômica e, à medida que avançou o século, o seu raio de ação aumentou significativamente. A estrutura apresentada pelo autor tendeu a se reproduzir em outras vilas mineiras nos Setecentos e de fato demandou, ao longo do século, uma ampliação do número de oficiais implicados exclusivamente com o juizado de órfãos das vilas. Em trabalho recentemente produzido por Juliana Godoy dos Santos sobre os juizados de órfãos nas Minas, enfatiza-se a natureza econômica das atividades desempenhadas por esse braço das câmaras, notadamente a administração dos bens dos órfãos e dos rendimentos obtidos com eles. Entretanto, a pesquisadora acrescenta que se tratava de um poder que envolvia responsabilidades amplas, que abrangiam não apenas o controle e administração dos bens dos órfãos - e consequentemente, das riquezas de Minas Gerais - como também parte significativa da sociedade que se encontraria desamparada do poder patriarcal. ${ }^{17}$

\footnotetext{
${ }^{15}$ MORAES, Fernanda Borges de. De arraiais, vilas e caminhos: a rede urbana das Minas coloniais. In: RESENDE, Maria Efigênia Lage de E VILLALTA, Luiz Carlos (org.). História de Minas Gerais: as Minas setecentistas, vol. 1. Belo Horizonte: Autêntica, 2007, p. 76-77.

${ }^{16}$ VENANCIO, Renato Pinto. Termo de Mariana. História e documentação, vol. I. Ouro Preto: Editora da Universidade Federal de Ouro Preto, 1998, p. 139.

${ }^{17}$ SANTOS, Juliana Godoy. Juizado de Órfãos em Minas colonial, século XVIII. In: XXVII SIMPÓSIO NACIONAL DE HISTÓRIA, ANPUH, jul. 2013, p. 3. Disponível em: http://www.snh2013.
} 
Nesse sentido, os juizados de órfãos, além de exercerem um controle sobre o processo de transmissão das heranças, assumiam as tarefas de nomear e controlar tutores e curadores, fiscalizar a educação dos órfãos, conceder licenças para casamento dos órfãos das vilas e algumas outras atribuições prescritas nas ordenações do Reino e que extrapolavam bastante aquelas de natureza estritamente econômica.

Todas as atribuições mencionadas acima e ainda outras de responsabilidade dos juízes dos órfãos, seus escrivães e demais oficiais que compunham o juizado de órfãos estão regulamentadas no livro 1, título 88 das Ordenações Filipinas. Há apenas um único parágrafo no qual se faz menção à responsabilidade do juiz de órfãos sobre os dementes, o qual destaca que eles têm jurisdição apenas sobre os feitos cíveis dos órfãos, desassisados ou pródigos, ou desmemoriados, que tiverem curadores nomeados. Resguardase a jurisdição dos juízes ordinários no que diz respeito aos feitos crimes em caso e autores órfãos e desassisados. Com exceção do parágrafo citado não há mais detalhes sobre as responsabilidades dos juízes de órfãos em relação aos indivíduos declarados incapazes pela Justiça.

A questão da separação de atribuições entre os juízes ordinários e juízes de órfãos, regulamentada pelo Alvará de 2 de maio de 1731, sob a alegação de que com o crescimento populacional no Brasil os juízes ordinários não conseguiam administrar bem os bens e heranças dos órfãos, mobilizou os ministros régios que então atuavam em Minas. O ouvidor Diogo Cotrim de Souza, o qual atuou na Comarca do Rio das Velhas, em 6 de setembro de 1730 enviou carta ao rei na qual constam informações detalhadas sobre contas que fez às câmaras de Sabará e Caeté por ocasião das correições e com base nelas concluiu que era necessário separar o ofício de juiz dos órfãos do cargo de juiz ordinário em todas as vilas daquela comarca. ${ }^{18}$ Feita a consulta ao Conselho Ultramarino em 2 de dezembro de 1730 sobre a informação dada pelo ouvidor geral do Rio das Velhas, os conselheiros resolveram que, a partir de 1731, se deveria passar ordens aos ouvidores para que nas eleições das justiças municipais também elegessem um juiz de órfãos trienal para todas as vilas.

O ouvidor em sua carta elaborou uma série de argumentos que justificavam a criação de um juizado de órfãos separado dos juízes ordinários. Primeiramente alega que o juiz de órfãos deveria conhecer matérias espe-

anpuh.org/resources/anais/27/1372282311_ARQUIVO_ArtigoANPUH2013-JulianaGodoySantos_1_.pdf. Acesso em: 25/09/2015.

${ }^{18}$ AHU, Minas Gerais, caixa 16, doc. 102. 
cíficas do direito de herança e que muitos juízes ordinários não possuíam tal conhecimento. Além disso, afirma que o período de um ano que os juízes permaneciam em seu cargo era incompatível com o acompanhamento adequado da execução dos inventários de órfãos. Portanto, o ouvidor fazia a defesa de juízes de órfãos perpétuos e não apenas trienais. Na informação aos conselheiros ele afirma que

\begin{abstract}
...suposto estes ministros tenham, como se presume, a perícia das leis, estabelecida para seu cargo, não têm e nem podiam ter todo o conhecimento das pessoas e bens dos que lhes são encarregados; e muito menos podem fazer a sua obrigação os juízes ordinários, e costumam todos estes ministros temporais (juízes de órfãos trienais) descarregar a sua obrigação nos escrivães, que quase sempre ficam árbitros absolutos de tão importantes matérias, o que regularmente não sucede com os juízes perpétuos. ${ }^{19}$
\end{abstract}

O que se depreende das razões apontadas pelo ouvidor é que ao juiz de órfãos não bastaria apenas conhecer as leis, mas deveria também conhecer as pessoas e ter domínio sobre o funcionamento das relações sociais na localidade para cumprir bem o seu papel e designar bons tutores e curadores. Desse conhecimento sobre as pessoas das diversas localidades sob sua jurisdição dependia o funcionamento adequado e o desempenho satisfatório das atribuições de seu cargo que envolvia o cuidado com os órfãos. É também importante a informação que traz dos escrivães de órfãos e a relevância que eles acabavam ganhando em uma estrutura que tivesse o juiz de órfãos trienal ou anual. O oficio de escrivão não era eletivo e pertencia a um conjunto de ofícios concedidos em serventia mediante o pagamento de donativos, terças partes e novos direitos à Real Fazenda. Teixeira Coelho apresenta a lista de todos esses ofícios e os valores pelos quais eles eram concedidos. Para exercer o ofício de escrivão dos órfãos de Sabará era necessário pagar a Real Fazenda um donativo de 1:640\$000 (um conto, seiscentos e quarenta mil réis); $400 \$ 000$ (quatrocentos mil réis) de terça parte anual e $120 \$ 000$ (cento e vinte mil réis) de novos direitos anualmente, que eram calculados sobre a estimativa dos rendimentos que se poderia ter com o exercício dos ofícios. Apesar disso representar possibilidades de ganhos muito significativos para o escrivão dos órfãos, Teixeira Coelho também salienta que no "ano de 1777 se estavam devendo à Real Fazenda, de donativos e terças-partes dos ofícios, 344:764\$089 réis" e afirma que a cobrança dessa dívida pela Real Fazenda era

$\overline{19}$ AHU, Minas Gerais, caixa 16, doc. 102. 
"dificultosa" e até mesmo "impossível" porque não se arrematavam as serventias à vista em dinheiro, eram concedidas por meio de fianças dos bens pertencentes ao arrematante e seus fiadores e não era conveniente executá-las. ${ }^{20}$

Ele também propôs que se regulamentassem os ganhos dos juízes e demais oficiais pertencentes ao juizado de órfãos para se evitar a dilapidação dos bens dos menores. Os conselheiros ultramarinos deram pareceres favoráveis a quase todas as informações do ouvidor e aprovaram um regimento provisional para os juízes de órfãos no qual especificaram os emolumentos e ganhos que todos os ofícios do juizado dos órfãos poderiam obter. Recusaram os juízes de órfãos perpétuos, permanecendo assim a eleição para juízes trienais juntamente com as eleições para os demais cargos das câmaras municipais.

De toda a legislação e documentos consultados nos quais ficam registradas as atribuições dos juízes de órfãos, sobressaem-se os aspectos que se referem à administração dos bens e transmissão de heranças e alguns poucos que dizem respeito à educação e cuidados gerais que deveriam dispensar aos órfãos.

Os poucos trabalhos existentes sobre os juízes de órfãos em Minas concentraram-se também em duas questões, em primeiro lugar, nas transmissões e administração das heranças deixadas aos órfãos; em segundo lugar, nos cuidados dispensados não apenas aos órfãos que possuíam bens, mas a todos os órfãos em geral, para os quais deveriam ser nomeados tutores. As questões da propriedade, da riqueza, da família, orfandade e do abandono das crianças são amplamente discutidas por essa historiografia. Duas preocupações de natureza distinta, uma vinculada à possibilidade de interferência na vida material e econômica dos súditos da capitania e a outra a associada à manutenção da ordem pública. Nesse último caso, educar e instruir os órfãos, de acordo com as qualidades de cada um, enquadrava-se nas expectativas dos súditos quanto à aplicação da justiça pelo monarca e, ainda, na necessidade de assegurar-se um ordenamento social. Contudo, não há nenhuma pesquisa que tenha se dedicado, no contexto do século XVIII nas Minas, ao papel dos juizados de órfãos no que diz respeito ao acompanhamento dos desassisados, mentecaptos, dementes, pródigos, desmemoriados que foram declarados incapazes pela Justiça e que eram também da responsabilidade do juizado dos órfãos.

\footnotetext{
${ }^{20}$ COELHO, José João Teixeira. Instrução para o governo da Capitania de Minas Gerais. Introdução de Francisco Iglesias. Belo Horizonte: Fundação João Pinheiro/CEHC, 1994, p. 224.
} 


\section{Os inventários de dementes e a administração da loucura na Comarca do Rio Das Velhas no século XVIII}

Aos juízes de órfãos coube a responsabilidade de administração da loucura na Comarca do Rio das Velhas em Minas Gerais no século XVIII. Na verdade, segundo o que consta no livro IV das Ordenações Filipinas, título CIII, ${ }^{21}$ a determinação para que os juízes de órfãos nomeassem curadores aos desassisados e desmemoriados, e aos pródigos, gastadores de suas fazendas, era atribuição que pertencia a esses juízes no reino e no ultramar como um todo. Nas ordenações manda-se que

tanto que o Juiz de órfãos souber que em sua jurisdição há algum sandeu, que por causa de sua sandice possa fazer mal, ou dano algum na pessoa, ou fazenda, o entregue a seu pai, se o tiver, e lhe mande de nossa parte que dahi em diante ponha nele boa guarda, assim na pessoa, como na fazenda; e se cumprir o faça aprisoar, em maneira que não possa fazer mal a outrem (p. 1005).

Vários parágrafos detalham outros aspectos das providências que deveriam ser tomadas pelo juiz de órfãos em relação aos dementes tais como: fazer inventário de todos os bens pertencentes ao indivíduo declarado incapaz, nomear um curador idôneo caso não tivesse pai, e que receberia os bens inventariados, dentre muitos outros aspectos que esclarecem sobre a atuação da Justiça em relação à loucura naquele período. A legislação em questão e os estudos de casos dos inventários de dementes pesquisados na região da Comarca do Rio das Velhas constituem-se fontes preciosas para se compreender melhor a história da loucura no século XVIII nas regiões periféricas do Império português, permitindo assim romper com certas generalizações reproduzidas frequentemente nos trabalhos existentes sobre o tema.

Desde a publicação da obra de Foucault (1972), A história da loucura na Idade Clássica, ela se tornou referência para todos os estudos que pretendessem abordar o tema da loucura nas mais variadas perspectivas, não apenas na área da história. Segundo a historiadora Patrícia O'Brien, a obra de Foucault tem sido "atacada e louvada" pelos historiadores, e quase sempre muito mal compreendida porque "não foi apreendida de fato pelo que ela é: uma alternativa

\footnotetext{
${ }^{21}$ Ordenações Filipinas online. Disponível em: http://www1.ci.uc.pt/ihti/proj/filipinas/l4ind. htm. Acesso em: 21-07-2015.
} 
para a escrita da história cultural".22 Em outra obra recente, a História da loucura, de Claude Quétel, ${ }^{23}$ o autor reafirma que a obra de Foucault é a fundadora dos estudos da história da loucura e que não é possível abordar o tema do internamento dos insanos no Antigo Regime sem fazer referência à sua tese.

É importante ressaltar de início sobre obra de Foucault duas passagens: "o internamento dos alienados é a estrutura mais visível na experiência clássica da loucura" 24 e outra quando afirma que "no seu funcionamento, ou no seu propósito, o hospital geral não se aparenta a qualquer ideia médica. Ele é uma instância da ordem, da ordem monárquica e burguesa que se organiza em França nessa mesma época". ${ }^{25}$ Como seria possível aproximar essa experiência clássica da loucura, marcada pelo internamento dos alienados, explicitada nos estudos de Foucault, das outras que ocorreram em espaços distintos? Sabe-se que no caso da América portuguesa e mais especificamente em Minas, no mesmo período, não houve nada semelhante ao "internamento de alienados" dos estudos de Foucault.

Não existiam casas de internamento ou trabalho como as que surgiram na Europa desde o século XVII. E também não se fundou em Minas nenhuma instituição semelhante ao que foi o Hospital Geral em França, apesar de o autor ressaltar que ele não foi um estabelecimento médico, sendo mais uma estrutura semijurídica e administrativa. Em que medida é possível estabelecer um paralelo entre as leis e a atuação dos juízes de órfãos em relação aos dementes nas Minas, o que refletia a preocupação da Coroa em relação aos processos de controle e ordenamento social, e a experiência clássica da loucura na Europa do mesmo período tal como foi estudada por Foucault? Ou a loucura e sua história nas Minas e em outras regiões periféricas, em relação às metrópoles europeias, foram tão singulares que não seria possível pensá-las a partir das conclusões de Foucault?

Para o caso específico do Brasil, os estudos que têm como problema de pesquisa a loucura se dedicaram quase que exclusivamente a um recorte temporal posterior ao período colonial. Uma grande parte deles se vincula ao Programa de Pós-graduação em História das Ciências e da Saúde da Fiocruz, conforme demonstrado por Yonissa Marmitti Wadi, e são trabalhos

\footnotetext{
${ }^{22}$ O'BRIEN, Patrícia. A história da cultura de Michel Foucault. In. HUNT, Lynn. A nova história cultural. São Paulo: Martins Fontes, 1992, p. 34-35.

${ }^{23}$ QUÉTEL, Claude. História da loucura: da Antiguidade à invenção da psiquiatria, vol. 1. Lisboa: Edições Texto e Grafia, 2014.

${ }^{24}$ FOUCAULT, Michel. História da loucura na Idade Clássica. São Paulo: Perspectiva, 2014, p. 48.

${ }^{25}$ Idem, p. 50.
} 
rev. hist. (São Paulo), n.176, a07616, 2017 http://dx.doi.org/10.11606/issn.2316-9141.rh.2017.121615
Maria Eliza de Campos Souza

Os inventários de dementes: os processos de curadoria e a relação da justiça régia com a loucura nas Minas Gerais do século XVIII

que, pela aproximação teórica com as discussões feitas por Foucault, tenderam a desenvolver discussões no campo da história social da medicina e da história cultural e a reduzirem a escala de observação.

A maioria dos trabalhos existentes - artigos, dissertações e teses - privilegiaram o período transcorrido entre os anos 1890 a $1966^{26}$ e são trabalhos que buscaram estudar a constituição e a consolidação das instituições de acolhimento aos alienados, hospitais psiquiátricos e da psiquiatria no país. Esta é a razão pela qual quase todos dialogam com a obra de Foucault, em grande medida buscando estabelecer uma interpretação de que a experiência da internação dos alienados e/ou a criação de hospitais de acolhimento específico para loucos no Brasil teria ocorrido tardiamente, de certo modo sugerindo certo "atraso" do Brasil em relação aos modelos de assistência implantados na Europa. Portanto, para muitos autores, a assistência aos indivíduos ditos loucos ${ }^{27}$ passou a ocorrer no Brasil apenas no século XIX e esteve associada ao processo de urbanização desse período, determinando "o estabelecimento de novos padrões de controle social, diferentes daqueles próprios à vida rural, supostamente mais complacente com tal circulação". ${ }^{28}$

A loucura antes desse período e a assistência aos indivíduos ditos loucos dependeriam das condições socioeconômicas de cada um, sendo que os "mentecaptos tranquilos pobres vagueavam pelas cidades" e os "agitados eram recolhidos às cadeias", conforme está descrito em "Notícia sobre a evolução da assistência a alienados no Brasil (1905)", escrito pelo então diretor do Hospício Nacional de Alienados, Juliano Moreira. ${ }^{29}$ Já em outro trabalho, Os delírios da razão, de Magali Engel, a autora salienta que

...a grande inovação da virada do século XVIII para o XIX constituir-se-ia em conferir à loucura uma especificidade ao se passar a concebê-la, sobretudo, como uma doença, buscando-se, desse modo, transformá-la em objeto de conhecimento e de intervenção exclusivos do médico. Entretanto, a medicalização não significaria apenas "a simples confiscação da loucura por um olhar médico", mas, principalmente, a "definição, através da

\footnotetext{
${ }^{26}$ WADI, Yonissa Marmitti. Olhares sobre a loucura e a psiquiatria: um balanço da produção na área de história (Brasil, 1980-2011). História Unisinos, vol. 18, nº 1, jan./abr. 2014, p. 129.

${ }^{27}$ GALDINI, Ana Maria Raimundo Oda E DALGALARRONDO, Paulo. O início da assistência aos alienados no Brasil ou importância e necessidade de estudar a história da psiquiatria. Revista Latinoamericana de Psicopatologia Fundamental, vol. VII, n. 1, mar. 2004, p. 128-159.

${ }^{28}$ Idem, p. 129.

${ }^{29}$ Transcrição e atualização feita por Ana Maria Galdini Raimundo Oda do texto publicado originalmente em Archivos Brasileiros de Psyquiatria, Neurologia e Sciencias Affins, vol. 1, n. 1, 1905, p. 52-98. Revista Latino Americana de Psicopatologia, vol. 14, n. 4, São Paulo, p. 728-768.
} 
instituição médica, de um novo status jurídico, social e civil do louco", transformando-o em alienado e fazendo da loucura uma "problemática indissociavelmente médica e social"30.

A autora aponta para uma distinção que se deve atribuir à loucura nesses dois momentos de nossa história, o que é muito relevante quando se busca compreender a assistência ou o tratamento conferido aos indivíduos ditos loucos. A maneira como a sociedade concebe a loucura tem reflexos no que se poderia traduzir como cuidados ou a ausência deles em cada momento. Desse modo, aquelas generalizações não parecem se adequar bem ao contexto das Minas setecentistas a partir do que se evidenciou com os estudos de casos feitos a partir dos inventários, principalmente a sugestão de uma loucura desassistida no período colonial. Certamente estas afirmações não correspondem ao que foi possível identificar nos inventários estudados em relação à atuação que a Justiça régia teve frente aos indivíduos declarados incapazes, conforme será visto. Os estudos apontam para a realidade que se distancia tanto do modelo assistencial aos alienados estudado por Foucault em sua obra História da loucura na Idade Clássica e por Claude Quétel em História da loucura: da Antiguidade à invenção da psiquiatria, os quais abordaram o tema da história da loucura com recorte espacial para a Europa. Também se distanciam de um discurso sobre uma loucura desassistida, aprisionada em cadeias, abandonada às ruas e ignorada pelas instituições político-administrativas ao longo do período colonial.

\section{O perfil dos dementes de Vila Real de Nossa Senhora da Conceição do Sabará}

Para discutir o perfil dos indivíduos estudados nessa pesquisa faz-se necessária uma breve reflexão sobre a sociedade na qual estavam inseridos. A formação e as características da sociedade mineira setecentista têm sido objeto de ampla discussão historiográfica, ${ }^{31}$ sendo relevante para os objetivos desta pesquisa enfatizar a questão dos limites para a reprodução do modelo estamental do centro nas periferias do Império português e das singularidades atribuídas às Minas. Os aspectos apontados pela historiografia para conferir singularidade à sociedade mineira são bastante variados e relacio-

\footnotetext{
${ }^{30}$ ENGEL, Magali Gouveia. Os delírios da razão: médicos, loucos e hospícios (Rio de Janeiro, 1830-1930) [online]. Rio de Janeiro: Editora Fiocruz, 2001, 352 p. (Loucura \& Civilização collection).

31 STUMPF, Roberta Giannubilo. A sociedade da Capitania das Minas Gerais. In: Idem. Os cavaleiros do ouro e outras trajetórias nobilitantes nas Minas setecentistas. Belo Horizonte: Fino Traço, 2014, p. 99-184.
} 
rev. hist. (São Paulo), n. 176, a07616, 2017 http://dx.doi.org/10.11606/issn.2316-9141.rh.2017.121615
Maria Eliza de Campos Souza

Os inventários de dementes: os processos de curadoria e a relação da justiça régia com a loucura nas Minas Gerais do século XVIII

nam-se em alguns casos à natureza das atividades econômicas nela desenvolvidas, à composição e variedade étnicas ali presentes, ao elevado número de alforrias, dentre outros elementos. ${ }^{32}$ Nesse amplo debate historiográfico é importante a ênfase dada por alguns autores à fluidez e indistinção ${ }^{33}$ como características resultantes desse processo singular da formação social das Minas e, por outro lado, existência de muitos paradoxos oriundos da "relevância atribuída pelos mineiros aos valores estamentais típicos das sociedades do Antigo Regime",34 mas, também, a outros valores societários trazidos por uma diversidade étnica de homens e mulheres que fizeram parte da construção desse espaço. Esses são aspectos importantes a serem considerados na compreensão de muitos dos casos analisados nesta pesquisa. Nesse sentido, essa sociedade mineira, a qual pertenceu esse grupo variado de indivíduos declarados dementes, "se constituía muito frequentemente à margem dos poderes instituídos ou na resistência à essa opressão", 35 uma vez que as instituições presentes nas Minas, apesar de pretenderem alcançar um certo ordenamento e controle social, nem sempre logravam cumprir esse papel.

A amostragem de inventários de dementes foi selecionada de um conjunto maior de fontes cartorárias composto por testamentos, inventários orfanológicos, justificações, e autos sumários avulsos pertencentes ao Arquivo Casa Borba Gato do Museu do Ouro em Sabará. Foram encontrados apenas dezesseis processos para todo o século XVIII, espacialmente distribuídos na Vila de Sabará e seu termo. São fontes muito representativas do ponto vista da atuação dos juizados de órfãos em relação aos indivíduos considerados pela comunidade como loucos, dementes, desassisados, mentecaptos, dentre outras denominações utilizadas nos próprios inventários e/ou sumários de demência.

É relevante dizer que os indivíduos analisados neste trabalho não podem ser classificados de mendigos, miseráveis ou indigentes, ${ }^{36}$ mas alguns deles podem ser enquadrados no grupo social que Laura de Mello e Souza nomeou como desclassificados sociais. ${ }^{37}$ Portanto, homens e mulheres po-

\footnotetext{
32 STUMPF, Roberta Giannubilo, op. cit., p. 100.

33 SOUZA, Laura de Mello e. Desclassificados do Ouro. A pobreza mineira no século XVIII. Rio de Janeiro: Editora Graal, 1982, p. 143 e SILVEIRA, Marco Antônio. Universo do indistinto. São Paulo: Hucitec, 1997.

${ }^{34}$ A autora chama atenção para o fato de que a "ambição de se distinguir era tanta que sua vulgarização acentuou a fluidez". STUMPF, Roberta Giannubilo, op. cit., p. 184.

35 FURTADO, Júnia Ferreira. Novas tendências da historiografia sobre Minas Gerais no período colonial. Revista História da Historiografia, nº 02, mar. 2009, p. 129.

${ }^{36}$ Sobre essas classificações ver FOUCAULT, Michel, op. cit., p. 82.

${ }^{37}$ SOUZA, Laura de Mello e. Desclassificados do Ouro. A pobreza mineira no século XVIII. Rio de Janeiro: Editora Graal, 1982, p. 143.
} 
bres, que estiveram sob o olhar atento da Justiça, não apenas nos casos de demência constatada por meio de autos sumários, mas, de modo mais amplo, pelo "ônus ou pela sua utilidade possível para região mineradora".38

Entre os dezesseis processos analisados, quatro são de pretas forras e dois são de pardos, correspondendo a 37,5\% do total. Os outros processos são de indivíduos do sexo masculino e em apenas dois deles declarou-se a cor branca e nos outros não se faz qualquer menção à cor do inventariado. ${ }^{39}$ Não foram encontrados inventários de mulheres brancas dementes nesta amostragem de processos referentes à Comarca do Rio das Velhas. Duas hipóteses foram levantadas para explicar, pelo menos em parte, a ausência de mulheres brancas entre os inventários e autos sumários de demência. A primeira delas, especialmente para a Comarca do Rio das Velhas, é a da predominância populacional de mestiços ou negros naquela região. ${ }^{40} \mathrm{~A}$ outra, mais importante, é a de que as poucas mulheres brancas pertencentes às elites locais, quando enlouqueciam eram provavelmente mantidas em cárcere privado, poderiam até receber algum tipo de tratamento, mas reclusas, sem que fosse necessário ou desejável a intervenção de um juiz, pois já estavam submetidas ao poder patriarcal. ${ }^{41}$

\footnotetext{
${ }^{38}$ Idem, p. 126.

${ }^{39}$ Para uma sociedade na qual o "desejo de distinção" era uma característica muito forte, é bastante significativo que o escrivão ou o juiz não tenham mencionado a cor na maior parte dos indivíduos inventariados declarados dementes. Na realidade é estranho que os dois inventários tenham mencionado a cor branca dos inventariados, já que "para a elite, os símbolos de distinção desempenhavam papel fundamental no reconhecimento de seu prestígio". SILVEIRA, Marco Antônio. Distinção e patetice: o caso do demente Manuel Pereira de Magalhães (Vila Rica, 1769). In: Idem. Dimensões do poder em Minas (séculos XVIII e XIX). Belo Horizonte: Fino Traço, 1997, p. 174-175.

${ }^{40}$ Ver CUNHA, Alexandre Mendes. Espaço, paisagem e população: dinâmicas espaciais e movimentos da população na leitura das vilas do ouro em Minas Gerais ao começo do século XIX. Revista Brasileira de História, vol. 27, nº 53, São Paulo, 2007, p. 123-128. Cedeplar/UFMG.

${ }^{41}$ SANTOS, Juliana Godoy. Juizado de Órfãos em Minas colonial, século XVIII. In: XXVII SIMPÓSIO NACIONAL DE HISTÓRIA, ANPUH. Anais. Jul. 2013, p. 3. Disponível em: http://www. snh2013.anpuh.org/resources/anais/27/1372282311_ARQUIVO_ArtigoANPUH2013-JulianaGodoySantos_1_.pdf. Acesso em: 25/09/2015, p. 5.
} 


\section{Quadro dos inventários pesquisados (1733-1795)}

\begin{tabular}{|c|c|c|c|}
\hline $\begin{array}{l}\text { Número do } \\
\text { processo }\end{array}$ & Ano & $\begin{array}{l}\text { Nome do inventariado/ } \\
\text { demente }\end{array}$ & Profissão/ detalhes \\
\hline CSO I (62) 463 & 1787 & José Rodrigues Aguiar & Pardo \\
\hline CSO I (60) 449 & 1786 & Ana de Araújo & Preta forra casada \\
\hline CSO I (70) 542 & 1795 & José de Bastos & \\
\hline CSO I (65) 487 & 1789 & Maria Correa & $\begin{array}{l}\text { Preta forra da Costa solteira } \\
\text { (o inventário foi anulado) }\end{array}$ \\
\hline CSO I (55) 412 & 1783 & José Rodrigues da Cruz & Inábil/minerador, pardo \\
\hline CSO I (20) 180 & 1759 & Antônio Gonçalves & Ferreiro \\
\hline CPO (01) 01 & 1772 & Rosa Gomes & Preta forra solteira \\
\hline CSO I (55) 417 & 1783 & Jacinta & $\begin{array}{c}\text { Preta mina forra } \\
\text { (testamento roubado) }\end{array}$ \\
\hline CSO I 03- 32 & 1733 & Manoel Gomes Assunção & \\
\hline CSO I (24)216 & 1764 & Antônio Almeida & \\
\hline CSO I (48) 365 & 1778 & João da Silva & Solteiro/curador dativo \\
\hline CSO I (12) 122 & 1748 & Domingos Martins Torres & Mentecapto/ solteiro \\
\hline CSO I (25) 221 & 1764 & Antônio da Rocha Lima & \\
\hline CSO I 18 (160) & 1756 & João de Souza Neto & Capitão / 100 anos \\
\hline CPO DEM (01) & 1773 & João Ferreira de Figueiredo & Demente/patetice/cego \\
\hline CSO I (21) 193 & 1760 & Manoel Francisco Pires & $\begin{array}{l}\text { Achado morto } \\
\text { atrás da estalagem }\end{array}$ \\
\hline
\end{tabular}

Fonte: produzido pela autora deste artigo a partir de levantamento feito no Arquivo Casa Borba Gato/Museu do Ouro em Sabará/MG. 
Com a política da Coroa de proibição da implantação de conventos e restrição às casas de recolhimento no território mineiro, ${ }^{42}$ não era provável que essas mulheres brancas loucas fossem levadas a esses locais ${ }^{43}$ e, no caso das famílias mais abastadas, pode ser que as enviassem para fora de Minas ou até mesmo para a Europa. No âmbito desta pesquisa não foi possível avançar muito em relação ao silêncio dos inventários no que diz respeito à demência das mulheres brancas.

A maioria dos inventários analisados era de indivíduos do sexo masculino, solteiros, alguns com filhos naturais. Em apenas um dos inventários aparece declaração casado como estado civil. Todos os inventários possuíam termo de abertura em que o escrivão do juízo dos órfãos declarava o motivo pelo qual o juiz estava realizando o inventário por demência. Neste termo sempre havia menção ao auto sumário de testemunhas, que havia sido feito anteriormente pelo juiz, e se este estava apenso ao processo ou não.

O principal aspecto dos termos de abertura é que consta nele uma breve descrição dos motivos, comportamentos pelos quais o indivíduo foi denunciado ou pelos quais "o juiz de órfãos teve notícia de dementes na Vila" para realizar o sumário de testemunhas. Dessas pequenas histórias foram selecionadas algumas para análise que faremos adiante ao tratar da atuação dos juízes frente à administração das curadorias dos dementes.

Constam algumas classificações recorrentes, mas que variavam até mesmo dentro do mesmo processo. Ou seja, um inventário de demência fazia menção para uma mesma pessoa de vários termos que na época utilizavamse para designar a loucura: demente, privado de juízo, desassisado, mente-

\footnotetext{
${ }^{42}$ Ao longo do século XVIII, não foram implantados conventos em Minas Gerais e funcionou, no território mineiro, apenas dois recolhimentos femininos, o de Macaúbas e o Vale de Lágrimas, fundados não por iniciativa da Igreja ou da Coroa, mas sim por leigos, que conseguiam licença episcopal para implantarem essas instituições, que eram sustentadas por doações e esmolas da própria comunidade. LAGE, Ana Cristina Pereira. Vale de Lágrimas: mulheres recolhidas no sertão de Minas Gerais na segunda metade do século XVIII. Revista de História Regional, vol. 19 , n. 2, 2014, p. 312-326.

43 Vários autores salientam a dificuldade de estabelecimento de casamentos legítimos em função da escassa população feminina branca nesse território, o que provavelmente tornou-se fator relevante para as restrições da Coroa quanto ao estabelecimento desse tipo de instituição nas Minas. LEWKOWICZ, Ida. Concubinato e casamento nas Minas setecentista. In: RESENDE, Maria Efigênia Lage de $\&$ VILLALTA, Luiz Carlos (org.). História de Minas Gerais: as Minas setecentistas, vol. 2. Belo Horizonte: Autêntica, 2007, p. 531-547. FURTADO, Júnia Ferreira. As mulheres nas Minas de ouro e diamantes. In: RESENDE, Maria Efigênia Lage de $\&$ VILLALTA, Luiz Carlos, op. cit., p. 481-504.
} 
capto, doido, assismada, furioso, visos de lunática, louca, falto de entendimento, patetice reconhecida, inábil e leso.

No que diz respeito às profissões apenas em três inventários consta declaração das atividades desenvolvidas pelo inventariado: Antônio Gonçalves, mestre ferreiro; José Rodrigues da Cruz, minerador; e João de Souza Neto, capitão. Entretanto, pelos bens que possuíam foi possível, em alguns casos, identificar as atividades profissionais que desenvolviam. Antônio da Rocha Lima era dono de uma fortuna avaliada em 20:480\$455 (vinte contos, quatrocentos e oitenta mil e quatrocentos e cinquenta e cinco réis), distribuídos entre várias fazendas, lavras minerais que tinha no rio das Velhas, grande número de escravos (o seu plantel demandava presença de feitores). É o único inventariado demente com fortuna significativa. O inventariado era minerador, ou melhor, vivia dos rendimentos de suas lavras e fazendas.

A maioria possuía casas de morada, vários bens móveis, alguns poucos escravos - entre 3 a 10 no máximo -, ouro lavrado e em pó, créditos e débitos, mas nenhum deles com monte-mor acima de dois contos de réis. Manoel Francisco Pires, José Bastos, José Rodrigues Aguiar, João da Silva, Domingos Martins, Manoel Gomes Assunção, João Ferreira Figueiredo e Antônio Almeida, pelos bens que possuíam, eram agricultores, pequenos mineradores, e pequenos comerciantes.

Não foi incomum a recusa de curadores nomeados pelos juízes de órfãos em aceitar governar a pessoa e bens dos dementes. Além da grande responsabilidade assumida por eles, já que deveriam prestar contas da boa administração e dos cuidados que dispensavam aos dementes de dois em dois anos, nos casos de dementes pobres, a curadoria poderia implicar em custos. Os casos e processos de curadoria, ou seja, toda a história desses indivíduos declarados incapazes, e depois de produzidos seus inventários, ajudam a compreender melhor as desventuras desses homens e mulheres ditos loucos nas Minas setecentistas. Foram escolhidas algumas das histórias dos dementes, homens livres e pretas forras para se compreender melhor como funcionava esse modelo assistencial dispensando pela Justiça régia no Antigo Regime português, em particular nas Minas setecentistas. 


\section{Os casos dos dementes da Vila de Sabará e atuação da Justiça}

\section{Três casos de demência masculina}

Aos vinte e três dias do mês de novembro de 1786, em casa de morada do guarda-mor Caetano Gomes da Mota, juiz de órfãos e dos pródigos e mentecaptos, foi feito o auto sumário de testemunhas para atestar a demência de José Rodrigues Aguiar. No auto sumário consta em seu termo de abertura que

...por ter ido a notícia que na cadeia desta Vila para onde tinha vindo preso se achava na mesma José Rodrigues de Aguiar, herdeiro que havia ficado do falecido Domingos Rodrigues de Aguiar, o qual se achava inteiramente louco e por consequência da dita louquice e falta de juízo fazendo alaridos grandes na dita cadeia de forma que perturbava e incomodava mas que na dita cadeia se achava não dizendo nos ditos alaridos cousa com cousa pelo que tivesse algum fundamento o seu dito e por causa do referido o soltaram para fora da prisão andando pelas ruas fazendo atos tão estranhos que por esse motivo se vem no conhecimento da demência que padece. ${ }^{44}$

Foram convocadas as três testemunhas, e, entre elas o carcereiro da cadeia que havia posto em liberdade o demente José Rodrigues Aguiar. O carcereiro, Serafim dos Anjos Batista, declarou em seu depoimento que colocou o sobredito, José Rodrigues Aguiar, homem pardo, "debaixo de chaves para apurar e que entrando o mesmo na dita prisão" começou a não dizer coisa com coisa e a fazer grandes alaridos e de muitas formas insultando os presos. E por esse motivo, ele o atirou para fora da cadeia, o qual passou a andar pelas ruas da vila, atrás de um terço, nu da cintura para cima, com os braços abertos e a provocar outros incidentes. No dia 25 de novembro, o juiz de órfãos julgou a demência por justificada e mandou que se procedesse ao inventário dos bens para entregá-los ao curador que deveria administrá-los e cuidar do demente.

Pelo inventário apurou-se que o único bem que José Rodrigues Aguiar possuía era uma escritura de compra e venda que seu pai fizera, em 1782, quando ainda era vivo, a Antônio Carvalho dos Santos e Manoel Carvalho dos Santos e sua mulher Maria Rodrigues da Cruz, de sua fazenda e todos

\footnotetext{
${ }^{44}$ Ibram/Museu do Ouro/Arquivo Casa Borba Gato. CSO I (62) 463, Inventário do demente José Rodrigues Aguiar, homem pardo.
} 
seus pertences. O valor da escritura de compra e venda era de 1:700\$000 (um conto setecentos mil réis), divididos em parcelas a serem pagas por 12 anos.

Assim que foi feito o inventário o juiz nomeou o curador Casimiro da Mota Magalhães, no dia 9 de julho de 1787, e mandou citar os devedores da herança do demente, para em juízo depositarem o que estavam devendo das parcelas atrasadas da escritura, para assistência ao demente. A partir desse momento, o juiz de órfãos atuou de forma regular nesse processo e constam várias notificações para os curadores prestarem contas, em 1789, 1791 e, sucessivamente, dentro dos prazos legais, os curadores eram acionados. Houve mudança de curador e, em 1798, o juiz de órfãos passou mandado de sequestro dos bens do curador em favor do demente. Se os curadores não administrassem bem e não dispensassem os cuidados necessários aos dementes, os juízes intervinham para resolver o problema. São vários vistos em correição que constam nesse processo até o ano de 1803, quando termina o inventário sem conclusão ou notícia da morte do demente. Este inventário é bastante singular por vários aspectos. Em nenhum dos inventários analisados o processo de curadoria foi tão extenso como este, ou teve tantas intervenções por parte dos juízes que atuaram ao longo de todo o período de dezesseis anos em que persistiu a curadoria do demente. Também, em nenhum outro caso de demência desta pesquisa, a sobrevida dos indivíduos declarados dementes depois de ser feito o inventário pela Justiça foi tão longa. A maioria dos inventariados dementes falecia em média após quatro anos de abertura do processo. E apesar do demente ter sido único herdeiro de seu pai, a herança consistia em uma dívida a ser cobrada, o que, no contexto das Minas e do seu complicado sistema de créditos e débitos, ${ }^{45}$ quase sempre se traduzia em incertezas. É importante mencionar que, além da prestação de contas da parte financeira, os juízes também estavam atentos aos cuidados dispensados aos dementes.

Em outro inventário, o de José Rodrigues da Cruz, ${ }^{46}$ homem pardo, solteiro, cujo sumário de testemunhas sobre sua demência foi feito em 1783, foi possível identificar um mesmo padrão nas intervenções da Justiça durante o processo de curadoria. Nesse caso, o auto sumário foi feito a partir de denúncia oculta. No desenrolar do processo, os denunciantes são mencio-

\footnotetext{
${ }^{45}$ SANTOS, Raphael Freitas. "Devo que pagarei": sociedade, mercado e práticas creditícias na comarca do Rio das Velhas (1713-1773). Dissertação de mestrado em História, UFMG, Belo Horizonte, 2005.

${ }^{46} \mathrm{Ibram} /$ Museu do Ouro/Arquivo Casa Borba Gato. CSO I (55) 412, Inventário do demente José Rodrigues da Cruz, homem pardo.
} 
nados pelo juiz e eram irmãos do demente. José Rodrigues vivia na casa de seu cunhado, casado com sua irmã, e seus três escravos: Maria moleca, José Angola Barbeiro e Miguel Mina já velho. No inventário consta que por "achar-se no estado de demência era necessário proceder à nomeação de um curador para bem administrar os bens e a pessoa do demente". Foi nomeado curador Pedro Rodrigues da Cruz, o qual era irmão do demente. No processo de inventário e curadoria são interpostas várias petições por meio das quais o juiz toma conhecimento das disputas entre os parentes do demente. O cunhado, Manoel Gomes Coelho, interpôs embargos contra o irmão e curador do demente, e a disputa chegou ao Tribunal da Relação do Rio de Janeiro, já que ele alegava que José Rodrigues da Cruz não era demente. Ao juiz de órfãos chega informação de que o curador, para quem foram entregues os bens do demente, ${ }^{47}$ não o tinha levado para viver com ele e nem os seus escravos que permaneceram todos na casa de Manoel Gomes Coelho e sendo sustentados e tratados sem qualquer ajuda do curador. O cunhado do demente, Manoel Gomes Coelho, denunciou ainda que os escravos e José Rodrigues não aceitaram ir para a casa de seu irmão curador por medo de maus tratos e que mesmo assim os jornais dos escravos e os rendimentos das lavras iam todos para ele. Em 1784, o juiz removeu o curador, tomou contas à revelia e nomeou outro, Tomás da Silva Pedroso. Em 1786, o juiz ordena nova prestação de contas e decide que todo rendimento dos bens que o demente possuía fosse aplicado para seu sustento e de seus escravos e que fossem bem tratados. Pelo processo, o demente e os escravos nunca deixaram a casa de Manoel Gomes, que nunca foi curador do demente. O último curador nomeado era advogado nos auditórios da Vila de Sabará e o processo se encerra com a arrematação dos bens do demente pelo seu cunhado, Manoel Gomes, em setembro de 1788. Pelas prestações de contas dos curadores o demente e seus escravos estavam sendo bem tratados e assistidos em suas moléstias pelo médico cirurgião.

Domingos Martins Torres, mentecapto, morador no arraial do Pompeu, homem solteiro e sem herdeiros, teve o seu inventário de bens feito pelo juiz de órfãos Francisco Seixas Brandão. No termo de abertura, em 1748, o juiz afirma que o "dito demente se acha louco, desassisado do juízo e falto do entendimento para poder reger e governar sua pessoa e bens", motivo pelo qual foi necessário fazer seu inventário para nomear curador. O de-

\footnotetext{
${ }^{47}$ Além dos escravos já citados, o inventariado possuía duas datas de terras minerais, 1/9 parte de datas minerais citas no rio Cuiabá e 1/9 parte de terras minerais.
} 
mente possuía apenas alguns pratos, poucos bens móveis, um escravo, e créditos que deviam a ele e dívidas que devia a outras pessoas. O curador nomeado, Manoel de Oliveira, em fins de 1748, faz uma petição ao juiz para que fosse aumentado o valor da diária de 12 vinténs destinados à alimentação do demente. O curador alegou que, por causa da loucura, Domingos Martins Torres "não tinha moderação com os alimentos e os desperdiça". Além disso, era necessário comprar "alimentos para o seu sustento como galinhas, vinhos, carnes concertadas com toucinho, pelo dito demente ser pessoa de idade de 65 para 66 anos e não poder se sujeitar por moléstia de que padece e fastio a comer o que usualmente come qualquer pessoa". ${ }^{48}$ Solicitou também a compra de camisa e calça para vestir o demente, e o juiz arbitrou o aumento dos alimentos e orientou que colocasse o escravo para o tratar. Nesse inventário consta ainda a petição do dr. Antônio Cialle que cobrava ao juiz de órfãos o pagamento de 14 oitavas de ouro, valor considerável, do inventário do demente em função das visitas e vários remédios particulares que ele havia dado a Domingos Martins no seu tempo de vida. Em 1753, consta o último registro do inventário no mês de outubro quando o demente falece e o curador presta contas.

Em todos esses inventários e autos sumários fica perceptível a ação frequente dos juízes tanto para averiguar e fazer cumprir a lei, apurando as denúncias e informações que chegavam a eles sobre pessoas com algum tipo de demência. Após a feitura dos inventários e a nomeação dos curadores, os juízes de órfãos mostravam-se vigilantes com as curadorias, tomavam contas de dois em dois anos, mandavam notificar os curadores nos casos de denúncia de irregularidades quanto à administração dos bens e cuidados com os dementes. Conforme foi visto, removiam curadores que não cumpriam o seu papel, sequestravam os bens dos mesmos se fosse necessário para repor os bens dos curatelados. E mesmo que nesses processos não se possa ter uma percepção muita clara sobre os favorecimentos que por vezes os juízes podiam conceder aos que integrassem suas redes sociais locais, é provável que isso tenha ocorrido. Entretanto, para discutir esses aspectos é necessário ampliar as fontes e o recorte espacial da pesquisa para outras comarcas de Minas. De qualquer forma, se o zelo demonstrado pelos juízes quanto à justiça dispensada aos indivíduos declarados dementes esteve relacionado com o poder de controle que detinham sobre a arrecadação desses bens e

\footnotetext{
${ }^{48} \mathrm{Ibram} /$ Museu do Ouro/Arquivo Casa Borba Gato. CSO I (12) 122, Inventário do demente Domingos Martins Torres.
} 
sua administração pelos curadores, ainda assim se quebra a imagem de uma loucura desassistida no Brasil colonial.

Passaremos agora a falar dos inventários e autos sumários de demência das pretas forras, que revelam outros aspectos da atuação da Justiça frente aos ditos loucos nas Minas do século XVIII.

\section{Os casos de demência das pretas forras}

O papel das pretas forras na sociedade mineira dos Setecentos tem sido amplamente discutido pela produção historiográfica recente, ${ }_{r}^{49}$ a qual buscou realçar certa liberdade desfrutada por esse grupo de mulheres, o seu protagonismo em certas atividades econômicas, que asseguravam a elas a possibilidade de assumirem a condição de "chefes de domicílios". 50 Os casos que vamos analisar demonstram quatro pretas forras da Vila de Sabará e seu termo ao se depararem com a Justiça em função da declaração de incapacidade a que foram submetidas pelo juizado de órfãos. Como foram conduzidos esses processos de inventários das pretas forras pelos juízes e qual foi o destino dessas mulheres pretas forras dementes?

O primeiro processo é o de Rosa Gomes, ${ }^{51}$ preta forra, nação mina, solteira, que teve o seu sumário de demência feito em 17 de agosto de 1772, pelo juiz de órfãos da Vila de Sabará, Caetano Gomes da Mota. As testemunhas do auto de demência apresentam, todas, um mesmo discurso sobre a preta forra Rosa Gomes e afirmam que:

...sabe pelo ver que Rosa é louca desassisada, digo e falta de juízo que ele testemunha tinha visto muitas vezes sair de casa gritando, sem dizer coisa com coisa e nua como nasceu maiormente pelas luas que provoca a sua doudice a maiores fúrias de sorte que

\footnotetext{
${ }^{49}$ Dentre os trabalhos mais recentes que buscaram demonstrar o papel e a relevância das pretas forras na sociedade mineira setecentista, as facilidades que elas tinham para conseguir alforria, a multiplicidade de arranjos familiares e até mesmo assumindo a chefia das famílias ver FIGUEIREDO, Luciano Raposo. Barrocas famílias: vida familiar em Minas Gerais no século XVIII. São Paulo: Hucitec, 1997; PAIVA, Eduardo França. Escravos e libertos nas Minas Gerais do século XVIII. São Paulo: Annablume, 1995; e principalmente os trabalhos de Júnia Ferreira Furtado. FURTADO, Júnia Ferreira. Chica da Silva e o contratador dos diamantes: O outro lado do mito. São Paulo: Companhia das Letras, 2003.

${ }^{50}$ FURTADO, Júnia Ferreira. Pérolas negras: mulheres livres de cor no distrito Diamantino. In: Idem. Diálogos oceânicos: Minas Gerais e as novas abordagens para a história do império ultramarino português. Belo Horizonte: Editora da UFMG, 2001, p. 82.

${ }^{51} \mathrm{Ibram} /$ Museu do Ouro/Arquivo Casa Borba Gato. CPO DEM (01) 01, Sumário de demência da preta forra de nação mina Rosa Gomes.
} 
atira pedradas a quem lhe parece santo que por falta de juízo atirou uma pedrada a uma vidraça que encerra a imagem do Senhor do Bonfim e mais não disse.

São cinco testemunhas que repetem a mesma história. O juiz declara demência por justificada e manda que se faça inventário dos bens que ela possuísse e nomeia curador para administrá-los e à pessoa de Rosa Gomes. Processo inconcluso, não foi encontrado o inventário e não se sabe nada sobre a curadoria e nem a data de falecimento.

Outro fragmento de inventário encontrado foi o de Ana Araújo, ${ }^{52}$ preta forra de nação mina, que foi casada com Francisco Correa Lacerda, já viúva e moradora em sua fazenda ao pé de Sete Lagoas. Por se tratar de um fragmento de inventario, as informações conseguidas são as que foram registradas no termo de abertura. No termo consta que Ana foi denunciada por seu próprio filho ao juizado de órfãos, o qual alegou que sua mãe não estava em seu juízo perfeito e que para não arruinar seus bens precisava de um curador. Por esse motivo o juiz a declarou incapaz, sequestrou e inventariou os bens de Ana Araújo. Há pouca informação sobre o que ocorreu nesse caso, mas tudo indica que o filho a teria denunciado para ser seu curador e administrar os bens deixados pelo seu pai à preta forra.

Outro inventário de demência de preta forra é o de Jacinta de nação mina, ${ }^{53}$ moradora na rua do Caquende na Vila de Sabará. O processo de inventário, com auto sumário apenso, permitiu reunir um pouco mais de informação sobre a história da preta forra e seu enlouquecimento. No caso deste auto sumário de demência, chama atenção o fato de ele pertencer a uma preta forra, viúva, sem herdeiros e de idade relativamente avançada, mas que possuía alguns bens. Jacinta, além de uma morada de casas, possuía escravos que, segundo as testemunhas, negociou com outras pessoas. Pelo depoimento de uma das testemunhas era católica e costumava frequentar a igreja, pois os padres não queriam mais ouvir suas confissões pelos despropósitos que dizia no confessionário. É provável que tenham sido seus vizinhos os informantes do juiz de órfãos sobre o suposto estado de incapacidade da preta forra Jacinta, já que se menciona no auto sumário o receio de que ela viesse a perder os poucos bens que possuía. Entretanto, também declarou

\footnotetext{
${ }^{52} \mathrm{Ibram} /$ Museu do Ouro/Arquivo Casa Borba Gato. CSO I (60) 449, Fragmento do inventário de demência da preta forra de nação mina Ana de Araújo, 1786.

53 Ibram/Museu do Ouro/Arquivo Casa Borba Gato. CSO I (55) 418, Inventário por demência e auto sumário de Jacinta, preta forra de nação mina, 1783.
} 
uma das testemunhas que ela havia dado os primeiros sinais de estar "avariada" há mais de quatro ou cinco anos e todas são unânimes em afirmar que sem a intervenção do juiz de órfãos e um curador, os poucos bens que possuía seriam arruinados. O depoimento de uma das testemunhas sugere que ela tinha relações próximas com um casal de vizinhos e que seus escravos e uma "criolinha" dela frequentavam a casa deles para aprender o oficio de cozer. Entretanto, percebem-se indícios de conflitos envolvendo dívidas que eles deviam a Jacinta e uma doação não explicada de uma "criolinha". É provável que os vizinhos e o grupo mais próximo a Jacinta, incluindo nele as testemunhas do auto sumário, tenham convivido com seus desatinos durante um bom tempo, antes que houvesse denúncia ao juizado de órfãos. Isso pode ter ocorrido tanto pelas vantagens que a situação poderia trazer aos envolvidos com ela diretamente os quais não denunciavam por conveniência. Como ela possuía alguns bens dos quais poderia retirar seu sustento e também favorecer a terceiros, inicialmente seus desatinos e gritos não representaram um problema efetivo para a comunidade próxima. $\mathrm{O}$ juiz de órfãos procedeu ao inventário e iniciou as notificações para nomeação de um curador e recebeu uma série de "escusas" da curadoria. Jacinta faleceu sem um curador, e os seus bens estavam em posse da viúva de João de Queiróz. O escrivão dos órfãos encerra o inventário com notificação para que herdeiros, se houvessem, reclamassem a herança.

Para finalizar vamos tratar do inventário de Maria Correa, ${ }^{54}$ preta forra da Costa da Mina, solteira. A inventariada possuía ouro lavrado, ouro em pó, abotoaduras de ouro, imagens com cordão de ouro, cinco anéis, muitas roupas de uso, ferros e três escravos. Foi feito o auto sumário da demência por denúncia de José Correa, o qual alegou que Maria se achava demente e falta de juízo, no ano de 1789. Entretanto, a preta forra entrou com requerimento e petição para nulidade do inventário, e correu processo após o qual por meio de exames e averiguações necessárias, o inventário foi anulado. Ela conseguiu provar judicialmente a falsidade da denúncia e o juiz de órfãos em 1791 julgou nulo por sentença o inventário, e mandou notificar o curador para fazer a entrega dos bens da inventariada. Em uma petição ao juiz de órfãos a demente informa que alguns de seus bens estavam em poder do escrivão anterior a Elias Fonseca Ramirez e outros em poder de seu acusador. O inventário de demência foi anulado e os bens devolvidos à preta forra em 1791 .

\footnotetext{
${ }^{54}$ Ibram/Museu do Ouro/Arquivo Casa Borba Gato. CSO I (65) 487, Inventário de demência da preta forra da Costa, Maria Correa, 1789.
} 
Este processo de inventário é emblemático, pois se trata de um processo de disputa clara entre a preta forra e seu denunciante, Gonçalo José Correa, com quem ela havia morado por uns tempos. Certamente, não sem ajuda de alguém, provavelmente do escrivão dos órfãos que tinha em seu poder alguns bens da suposta demente, Gonçalo José Correa conseguiu que a Justiça declarasse Maria Correa como incapaz. O que reflete os riscos que corriam mulheres como ela no século XVIII, preta forra e com alguns bens, joias e escravos, certamente fora do alcance direto de um poder patriarcal, e, portanto, em vários aspectos uma ameaça aos pequenos poderes. Por outro lado, demonstra não apenas que muitos casos de "demência" podiam ser revertidos e indivíduos ditos dementes podiam recuperar seu estado de capacidade jurídica, o que ocorreu também para o caso dos homens que fazem parte da amostragem trabalhada. Tratava-se nesse caso de voltar a fazer parte do pacto social, conforme salienta Antonio Manuel Hespanha (2010), e a preta forra, Maria Correa, soube mobilizar suas redes sociais para provar a falsidade da denúncia de demência feita contra ela. O autor citado em "Loucos, pródigos, falidos e viúvas gastadeiras" discutiu as condições para que os indivíduos participassem desse pacto social no Antigo Regime e afirma que o objeto do "pacto social é o convívio cívico e político". Portanto, eram os agentes da Justiça régia, como representantes da lei, que definiam, por critérios "políticos" e não médicos, se o indivíduo tinha perdido, definitiva ou temporariamente, em função de seu comportamento descrito por testemunhas, o direito de desfrutar da "plena liberdade e da plena racionalidade", que eram as bases do pacto social. Tornando-se incapazes, ainda assim os indivíduos poderiam recorrer dessa decisão e provar que não eram dementes ou loucos como foi o caso da preta forra Maria Correa. ${ }^{55}$

\section{Considerações finais}

Juízes atentos ao desenvolvimento do processo de curadoria, que fiscalizavam as ações dos curadores, tanto em relação à administração dos bens como no que diz respeito à alimentação e cuidados com os dementes, podem caracterizar certo modelo de assistência aos loucos próprio ao século XVIII em áreas periféricas em relação ao centro do Império português. No

\footnotetext{
${ }^{55}$ HESPANHA, Antonio Manuel. Imbecillitas: as bem-aventuranças da inferioridade nas sociedades de Antigo Regime. São Paulo: Annablume, 2010, p. 54.
} 
caso de Minas Gerais em particular, essa ação da Justiça esteve certamente relacionada à necessidade da Coroa de manutenção da ordem social. A própria comunidade era mobilizada para prestar cuidados aos dementes e nem sempre eram os parentes escolhidos como curadores.

Aparecem em vários processos nos autos de contas os vistos em correição com a determinação "Subsista o inventário e o curador trate o demente como hé obrigado", o que demonstra certa regularidade quanto às ações fiscalizadoras da Justiça nos casos de curadorias de dementes e também que averiguavam a necessidade de continuidade da mesma ou não. A noção de que a demência poderia ser temporária pode claramente ser percebida nos inventários e sumários de demência do período em questão. Os autos de contas também eram realizados para averiguar se o estado de demência permanecia, caso contrário poderia ser anulado e os bens entregues ao inventariado. A legislação do período previa esse aspecto e é o que consta dos artigos do Código Filipino que tratam da atuação dos juízes de órfãos em relação aos indivíduos declarados dementes. Enfatiza-se que a provisoriedade desse estado era uma possibilidade e que a loucura era em alguns casos reversível.

Não identifiquei nos processos analisados, nem mesmo nos de pessoas dementes abastadas, indícios diretos de corrupção por parte dos juízes que atuaram na Comarca do Rio das Velhas nas curadorias de dementes. Isto não quer dizer que não se tirava proveito, quer dizer apenas que essa fonte não é a mais indicada para comprovar atuação de juízes e escrivães corruptos. Afinal eram os juízes que escolhiam os curadores que administravam bens e muitas vezes com a indicação do escrivão dos órfãos. A próxima etapa desta pesquisa irá investigar as fontes adequadas para uma averiguação de atuações corruptas de juízes de órfãos em casos de demência. É necessário estender a pesquisa para outras comarcas de Minas, estabelecer comparações entre essas localidades e a administração da loucura praticada pelos juízes de órfãos e investigar outras fontes diferentes dos inventários e sumários.

Um aspecto ao longo dessa pesquisa chamou atenção: a maioria dos inventariados dessa amostragem morreu em média quatro anos após a abertura do inventário. Um dos dementes foi encontrado morto em condições suspeitas. Enfim, é preciso averiguar como esses indivíduos eram tratados de fato por seus curadores. As contas tomadas pelos juízes muitas vezes poderiam disfarçar maus tratos e a documentação não ofereceu indícios mais precisos sobre como esses indivíduos eram tratados do ponto de vista médico. Por essas razões faz-se necessário ampliar o escopo das fontes pesquisadas. Nesse sentido, temos ainda longo caminho a percorrer para conhecer de forma mais aprofundada o real alcance da atuação dos juízes de órfãos 
no que diz respeito aos indivíduos declarados dementes, os seus interesses e dos familiares envolvidos com os processos de curadorias, vizinhos e demais pessoas implicadas com o cumprimento de uma legislação aplicada de forma geral para espaços muito diversos.

\section{Referências bibliográficas}

ANASTASIA, Carla Maria Junho. América portuguesa: mais direitos, menos revoltas. In: COSENTINO, Francisco Carlos (org.). 1500-2000: Trajetórias. Belo Horizonte: Centro Universitário Newton Paiva Curso de História, 1999.

ANGELO, R. F. A loucura no século XVIII - Um estudo dos mentecaptos na Comarca do Rio das Velhas. In: II CONGRESSO DE CIÊNCIAS HUMANAS, LETRAS E ARTES. Anais. Uberlândia: Universidade Federal de Uberlândia, 27 de maio de 1995.

BICALHO, Maria Fernanda. A cidade e o Império. Rio de Janeiro: Civilização Brasileira, 2003.

BOXER, Charles R. O império marítimo português, 1415-1825. São Paulo: Companhia das Letras, 2002.

COELHO, José João Teixeira. Instrução para o governo da Capitania de Minas Gerais. Introdução de Francisco Iglesias. Belo Horizonte: Fundação João Pinheiro/ CEHC, 1994, 301p.

CUNHA, Alexandre Mendes. Espaço, paisagem e população: dinâmicas espaciais e movimentos da população na leitura das vilas do ouro em Minas Gerais ao começo do século XIX. Revista Brasileira de História, vol. 27, nº 53, São Paulo, 2007, p. 123-128. Cedeplar/UFMG.

DAVES, Alexandre Pereira. Vaidades das vaidades: os homens, a morte e a religião nos testamentos da Comarca do Rio das Velhas (1716-1755). Dissertação de mestrado em História, UFMG, Belo Horizonte, 1998.

ENGEL, Magali Gouveia. Os delírios da razão: médicos, loucos e hospícios (Rio de Janeiro, 1830-1930) [online]. Rio de Janeiro: Editora Fiocruz, 2001, 352 p. (Loucura $\mathcal{E}$ Civilização collection).

FIGUEIREDO, Luciano Raposo. Barrocas famílias: vida familiar em Minas Gerais no século XVIII. São Paulo: Hucitec, 1997.

FOUCAULT, Michel. História da loucura na Idade Clássica. São Paulo: Perspectiva, 2014. FURTADO, Júnia Ferreira. Novas tendências da historiografia sobre Minas Gerais no período colonial. Revista História da Historiografia, nº 02, mar. 2009, p. 116-162. Chica da Silva e o contratador dos diamantes: $O$ outro lado do mito. São Paulo: Companhia das Letras, 2003.

Pérolas negras: mulheres livres de cor no distrito Diamantino. In: Idem. Diálogos oceânicos: Minas Gerais e as novas abordagens para a história do império ultramarino português. Belo Horizonte: Editora da UFMG, 2001. 
As mulheres nas Minas de ouro e diamantes. In: RESENDE, Maria Efigênia Lage de $\mathcal{E}$ VILLALTA, Luiz Carlos (org.). História de Minas Gerais: as Minas setecentistas, vol. 2. Belo Horizonte: Autêntica, 2007.

GOUVÊA, Maria de Fátima Silva. Redes de poder na América portuguesa: O caso dos homens bons do Rio de Janeiro. 1790-1822. Revista Brasileira de História, vol.18, n. 36, 1998, p. 297-330.

HESPANHA, Antonio Manuel. Imbecillitas: as bem-aventuranças da inferioridade nas sociedades de Antigo Regime. São Paulo: Annablume, 2010, p. 54.

IGGERS, Georg. Desafios do século XXI à historiografia. Revista História da Historiografia, n. 04, Ouro Preto, mar. 2010, p. 105-124.

LAGE, Ana Cristina Pereira. Vale de Lágrimas: mulheres recolhidas no sertão de Minas Gerais na segunda metade do século XVIII. Revista de História Regional, vol. 19, n. 2, 2014, p. 312-326.

LEMOS, Carmen Silva. A justiça local: os juízes ordinários e as devassas da Comarca de Vila Rica (1750-1808). Dissertação de mestrado, Universidade Federal de Minas Gerais, Belo Horizonte, 2003.

LEWKOWICZ, Ida. Concubinato e casamento nas Minas setecentistas. In: RESENDE, Maria Efigênia Lage de $\mathcal{E}$ VILLALTA, Luiz Carlos (org.). História de Minas Gerais: as Minas setecentistas, vol. 2. Belo Horizonte: Autêntica, 2007, p. 531-547.

MAGALHÃES, Joaquim Romero. Concelhos e organização municipal na Época Moderna. Coimbra: Imprensa da Universidade de Coimbra, 2011.

MARCÍLIO, Maria Luíza. História social da criança abandonada. $2^{\mathrm{a}}$ edição. São Paulo: Hucitec, 2006.

MORAES, Fernanda Borges de. De arraiais, vilas e caminhos: a rede urbana das Minas coloniais. In: RESENDE, Maria Efigênia Lage de $\mathcal{E}$ Villalta, Luiz Carlos (org.). História de Minas Gerais: As Minas setecentistas, vol. 1. Belo Horizonte: Autêntica, 2007.

Ordenações Filipinas [online]. Disponível em: http://www1.ci.uc.pt/ihti/proj/ filipinas/l4ind.htm. Acesso em: 21/07/2015.

O'BRIEN, Patrícia. A história da cultura de Michel Foucault. In. HUNT, Lynn. A nova história cultural. São Paulo: Martins Fontes, 1992, p. 34-35.

ODA, Ana Maria Galdini Raimundo $\mathcal{E}$ DALGALARRONDO, Paulo. O início da assistência aos alienados no Brasil ou importância e necessidade de estudar a história da psiquiatria. Revista Latino-americana de Psicopatologia Fundamental, vol. VII, n. 1, mar. 2004, p. 128-159.

OLIVEIRA, Pablo Menezes. Cartas, pedras, tintas e coração: as casas de câmara e a prática política em Minas Gerais (1711-1798). Tese de doutorado, Universidade Federal de Minas Gerais, Faculdade de Filosofia e Ciências, 2013.

PAIVA, Eduardo França. Escravos e libertos nas Minas Gerais do século XVIII: estratégias de resistência através dos testamentos. São Paulo: Annablume, 1996.

PAULINELLI, Maysa de Pádua Teixeira. Narrativas da demência: análise de gêneros judiciários produzidos na região dos inconfidentes. Entremeios: Revista de Estudos do Discurso, vol. 10, jan.-jun. 2015. Disponível em: < http://www.entremeios.inf. br >. Acesso em: 22/07/2015. 
PIRES, Maria do Carmo. "Em testemunho da verdade": juízes de vintena e o poder local na Comarca de Vila Rica (1736-1808). Belo Horizonte: UFMG, 2005.

PORTER, Roy. Por uma história social da loucura. Rio de Janeiro: Jorge Zahar, 1990.

PRIORE, Mary Del (org.). História das crianças no Brasil. São Paulo: Contexto, 1999.

PROSPERI, Adriano. Dar a alma. São Paulo: Cia. das Letras, 2010.

QUÉTEL, Claude. História da loucura: da Antiguidade à invenção da psiquiatria, vol. 1. Lisboa: Edições Texto e Grafia, 2014.

RAMOS, Donald. A social history of Ouro Preto: stresses of dynamics urbanization in colonial Brazil, 1695-1726. Gainesville: University of Florida, 1972.

ROMEIRO, Adriana. Paulistas e emboabas no coração das Minas: ideias, práticas e imaginário político no século XVIII. Belo Horizonte: Editora da UFMG, 2008, 431 p.

SANTOS, Juliana Godoy. Juizado de Órfãos em Minas colonial, século XVIII. In: XXVII SIMPÓSIO NACIONAL DE HISTÓRIA, ANPUH, jul. 2013, p. 3. Disponível em: http://www.snh2013.anpuh.org/resources/anais/27/1372282311_ARQUIVO_ArtigoANPUH2013-JulianaGodoySantos_1_.pdf. Acesso em: 25/09/2015.

SANTOS, Raphael Freitas. "Devo que pagarei": sociedade, mercado e práticas creditícias na Comarca do Rio das Velhas (1713-1773). Dissertação de mestrado em História, UFMG, Belo Horizonte, 2005.

SILVEIRA, Marco Antonio. Distinção e patetice: o caso do demente Manuel Pereira de Magalhães (Vila Rica, 1769). In: Idem. Dimensões do poder em Minas (séculos XVIII e XIX). Belo Horizonte: Fino Traço, 2012, p. 139-155. Universo do indistinto. São Paulo: Hucitec, 1997.

VENÂNCIO, Renato Pinto. Famílias abandonadas - assistência à criança de camadas populares no Rio de Janeiro e em Salvador - séculos XVIII e XIX. São Paulo: Papirus, 1999.

VENANCIO, Renato Pinto. Termo de Mariana. História e documentação, vol. I. Ouro Preto: Editora da Universidade Federal de Ouro Preto, 1998.

WADI, Yonissa Marmitti. Louca pela vida: a história de Pierina. Tese de doutorado, Pontifícia Universidade Católica de São Paulo, São Paulo, 342 p.

Palácio para guardar doidos. Uma história das lutas pela construção do hospital de alienados e da psiquiatria no Rio Grande do Sul. Porto Alegre: Editora da UFRGS, 2002, 256 p.

Olhares sobre a loucura e a psiquiatria: um balanço da produção na área de história (Brasil, 1980-2011). História Unisinos, vol. 18, nº 1, jan./abr. 2014, p. 114-135. 250-269.

Entre muros: os loucos contam o hospício. Topoi, vol. 12, n. 22, p. 